\title{
Nutritional status and technological quality of sugarcane due to increasing gypsum doses
}

\author{
Paulo Ricardo Aprígio Clemente, Vinicius Santos Gomes da Silva*, Vilma Marques Ferreira, José Vieira \\ Silva, Geraldo Veríssimo de Souza Barbosa, Laurício Endres
}

\author{
Centro de Ciências Agrárias, Universidade Federal de Alagoas, Rio Largo, Alagoas, Brazil
}

*Corresponding author: vinicius.agro2008.1@gmail.com

\begin{abstract}
The sugar-energy sector is highlighted in Brazilian agribusiness; however, poor water distribution and soil acidity have limited the yield and quality of cane fields. Gypsum improves the physical and chemical properties of the soil, attenuating the effects of water shortage and acidity in the edaphic environment. The aim of this study was to determine the effect of gypsum doses on the nutritional status, photochemical efficiency and technological quality of sugarcane. The experiment was conducted under field conditions using a randomized block design in a $3 \times 5$ factorial scheme with four replications. The treatments consisted of the combination of three sugarcane varieties (RB011941, RB92579, and RB991536) with five doses of gypsum (0 Mg ha ${ }^{-1} ; 2.5 \mathrm{Mg} \mathrm{ha}^{-1}$; $5.0 \mathrm{Mg} \mathrm{ha}^{-1} ; 10 \mathrm{Mg} \mathrm{ha}^{-1}$; and $\left.20.0 \mathrm{Mg} \mathrm{ha}^{-1}\right)$. The results showed that gypsum did not influence the evaluated variables. A varietal effect for leaf contents of $P, K, M g$ and S was observed. The RB92579 presented the highest levels of $P\left(1.65 \mathrm{~g} \mathrm{~kg}^{-1}\right)$ and $\mathrm{K}(14.55 \mathrm{~g}$ $\mathrm{kg}^{-1}$ ), while RB011941 showed the highest concentrations of $\mathrm{Mg}$ and $\mathrm{S}, 1.25$ and $1.05 \mathrm{~g} \mathrm{~kg}^{-1}$, respectively. The mean values of the macronutrients presented the following concentration order: $\mathrm{N}>\mathrm{K}>\mathrm{Ca}>\mathrm{Mg}>\mathrm{P}>\mathrm{S}$. Genotypes were similar in terms of photochemical efficiency, which in turn, was not influenced by gypsum application. The best technological quality was verified in RB92579, which showed the highest Brix percentage (22.35\%), Pol (19.75\%), and the highest levels of TRS (151.3 $\left.\mathrm{kg} \mathrm{t}^{-1}\right)$ of sugarcane.
\end{abstract}

Keywords: foliar diagnosis, photochemical efficiency, nutritional efficiency, Saccharum spp.

Abbreviations: Brix_soluble solids; Pol_apparent sucrose in juice; TRS_theoretical recoverable sugar (TRS).

Introduction

Sugarcane is one of the most important energy crops in the world, showing the best net energy yield (Waclawovsky et al., 2010). In recent years, it has gained global interest as a raw material for the production of biofuels, since its energy balance is potentially positive (Smeets et al., 2009; Losordo et al., 2016). In the global scenario, Brazil stands out as the largest producer, whose production system is one of the most competitive in the world, mainly due to the development of national science and technology for the production of sugarcane, extraction and industrialization of the juice, use of sugar-alcohol waste in the fertilization of cane fields, and electric power generation (Clemente et al., 2017; Oliveira et al., 2017; Pereira et al., 2017).

Despite the promising scenario, currently, the sugarcane crop faces a serious agricultural and industrial crisis, marked by low yields of sugarcane plantations, especially in northeastern Brazil. For example, the state of Alagoas, which is the largest producer in the region, has an average stem yield of less than $60 \mathrm{t} \mathrm{ha}^{-1}$, well below the biological potential of the crop (Silva et al., 2017b).

The low yields in the Northeast are mainly related to the irregular seasonal distribution of rainfall (Oliveira et al., 2011a; Abreu et al., 2013; Silva et al., 2014) and marked acidity in soils (Clemente et al., 2017). In coastal tablelands, water deficiency occurs in spring-summer (Souza et al., 2004), which results in a lack of water during most of the plant growth period. Another fact that contributes to the low yield is the soil acidity effects associated with the presence of $\mathrm{Al}^{+3}$ in toxic concentrations, as well as the low levels of basic cations such as $\mathrm{Ca}^{+2}, \mathrm{Mg}^{+2}$ and $\mathrm{K}^{+}$, mainly in the subsurface soil layers (Souza et al., 2007).

Among the various agronomic practices being used to mitigate the effect of water deficit in plants, the use of gypsum deserves highlight. Gypsum improves root distribution in depth and allows plants to use larger volumes of water and nutrients, especially during drought periods (Souza et al., 2007; Clemente et al., 2017). Several researchers report that gypsum provides root deepening, resulting in an increase in stem yield (Morelli et al., 1992; Rocha et al., 2008) and sugars (Clemente et al., 2017), which may be related to improvement of the nutritional status and technological quality of sugarcane.

In view of the above, the aim of this study was to evaluate the nutritional status, photochemical efficiency, and technological quality of three sugarcane genotypes subjected to increasing doses of mineral gypsum.

\section{Results and discussion}

\section{Leaf nutrient content of sugarcane (nutritional status)}

The results of the analysis of variance showed that there was no interaction between varieties and mineral gypsum on the nutritional status of the plants (Table 1). Gypsum doses did 
not influence macronutrient leaf contents. On the other hand, the varieties differed for the contents of $\mathrm{P}, \mathrm{K}, \mathrm{Mg}$, and S.

The nitrogen content was similar for three varieties, where plants presented $14.61 \mathrm{~g} \mathrm{~kg}^{-1}$ on average (Table 2). Comparing this mean $\mathrm{N}$ content with those reported by Orlando Filho (1993), Malavolta et al. (1997), and Raij (2011), any value below the adequate concentration (16-21 $\mathrm{g} \mathrm{kg}^{-1}$ ) is considered deficient. The value that we observed in this experiment indicates that our plants are deficient in this nutrient. This fact is likely to limit growth and yield of sugarcane, since $\mathrm{N}$ is the second most demanded macronutrient by sugarcane (Oliveira et al., 2010), acting on the synthesis of chlorophyll, essential amino acids, and providing the energy necessary for the production of carbohydrates and carbon skeletons, directly reflecting the development and yield of the crop (Canfield et al., 2010; Marschner, 2012; Bloom, 2015).

Leaf $\mathrm{N}$ content was expected to be within the range considered adequate (16-21 $\mathrm{g} \mathrm{kg}^{-1}$ ) (Orlando Filho, 1993; Malavolta et al., 1997; Raij, 2011), since in the sugarcane reform, calcium and gypsum application and soil tillage increase soil microbial activity and there is a higher rate of mineralization of soil organic matter, especially from crop remains and rhizomes of the previous crop. Thus, the nitrate content in the soil solution is increased. This results in higher efficiency of the plants in nitrate uptake in association with the high availability of phosphorus in the soil (Silva et al., 2017a).

Regarding the phosphorus content, RB92579 presented the highest concentration of the element $\left(1.65 \mathrm{~g} \mathrm{~kg}^{-1}\right)$, about $30 \%$ higher than two other genotypes, which in turn, did not differ from each other (Table 2). Considering the high availability of $P$ in the soil $\left(46 \mathrm{mg} \mathrm{dm}^{-3}\right.$ phosphorus in the 0 $20 \mathrm{~cm}$ layer, extracted with Mehlich-1), the plants should also have high leaf contents of P. However, only RB92579 presented leaf contents in the range considered adequate (Orlando Filho, 1993; Malavolta et al., 1997; Raij, 2011). The other two genotypes, RB011941 and RB991536, were deficient in this nutrient. Although phosphorus is the macronutrient that is less required by sugarcane (Oliveira et al., 2011b), its adequate supply is fundamental for the growth, development, and yield of sugarcane, since it participates in most metabolic energy transfers, acts as an intermediary in the synthesis of numerous complex molecules and can regulate the rate of various enzymatic reactions and processes such as respiration, glycolysis, photosynthesis and starch synthesis and degradation (Calheiros et al., 2012; Marschner, 2012; Sousa et al., 2013; Simões Neto et al., 2015).

In a study conducted with varieties RB92579 and RB867515 in a soil with high $P$ content (mean values higher than 103 $\mathrm{mg} \mathrm{dm^{-3 }}$ phosphorus, extracted with Mehlich-1) in the Zona da Mata of Alagoas, Silva et al. (2017a) found leaf P contents lower than $1.6 \mathrm{~g} \mathrm{~kg}^{-1}$, implying, inadequate supply of this element according to Orlando Filho (1993) and Malavolta et al. (1997). Notwithstanding, the mean yield was $126 \mathrm{t}$ stems per hectare. This fact along with other observations for sugarcane plantations of high yields and with leaf $\mathrm{P}$ content below $2.0 \mathrm{~g} \mathrm{~kg}^{-1}$, Silva et al. (2017a) asked whether the reference values of Orlando Filho (1993) and Malavolta et al. (1997) would be adequate for the assessment of P levels.
For potassium, similar to phosphorus, the highest content was found in RB92579 $\left(14.55 \mathrm{~g} \mathrm{~kg}^{-1}\right)$, while the lowest was obtained by RB011941 (13.55 $\mathrm{g} \mathrm{kg}^{-1}$ ). These results indicate that the cultivars presented foliar contents considered adequate by Orlando Filho (1993), Malavolta et al. (1997), and Raij (2011). An adequate content of this element is of great importance for sugarcane, due to the participation of potassium in tissue turgidity regulation, enzymatic activation, opening and closing of stomata, carbohydrate transport, transpiration, and resistance to frosts, drought, diseases, and lodging (Flores et al., 2012).

The potassium contents of Leaf was predicted adequate as a result of the base fertilization with $130 \mathrm{~kg}$ of $\mathrm{K}_{2} \mathrm{O}$, and considering that the potassium contents in the soil were four times higher than the critical level established by Chalita (1991), which is $1.5 \mathrm{cmol} \mathrm{dm}^{-3}$ for cane plant. It is important to consider that although the soil contents are high, the foliar concentrations in the plants indicate a good nutritional status, indicating no elemental excess. This fact is important, because excessive amounts of potassium hinder the industrial process of sugar production. It makes crystallization of sugar difficult of due to the formation of false nuclei, reducing the sugar yield (Silva et al., 2017b).

Regarding leaf calcium, a variation between 3.0 and $3.6 \mathrm{~g} \mathrm{~kg}$ 1 was observed. In a study conducted in the Brazilian northeast, a were similar result was observed by Moura Filho et al. (2014), whose mean leaf calcium content of 10 sugarcane varieties was $3.1 \mathrm{~g} \mathrm{~kg}^{-1}$. The foliar values obtained in this work are in the range considered adequate by Raij (2011). Such results were expected, since the soil had high calcium contents before conduction of (Raij, 2011), and received the application of limestone in sufficient quantity to raise base saturation of $60 \%$, in addition to the application of mineral gypsum.

The magnesium content differed between the sugarcane genotypes. Genotype RB011941 presented the highest content, while the lowest concentrations were presented by RB92579. The values obtained are within the appropriate range established by Raij (2011). The adequate contents of the present study can be explained by the soil Mg contents (Table 2) being above the critical level of this element, which

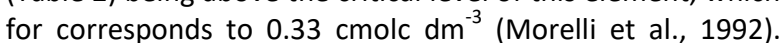
This resulted in a good supply of the element in association with the application of dolomitic limestone (>12 MgO).

Calcium and magnesium are very important for the growth of sugarcane. Plants extract, $0.92-1.52 \mathrm{~kg} \mathrm{t}^{-1}$ of calcium in the stems, while for magnesium the extraction varies from 0.35 $0.50 \mathrm{~kg} \mathrm{t}^{-1}$ according to Oliveira et al. (2010). The high demand for these elements rose from the participation of calcium in the cell wall, which is important in the functioning of intercellular membranes, explaining the coordination capacity of the element as structural component in intermolecular bonds. In turn, magnesium, besides the structural participation in the chlorophyll molecule, participates with phosphates as a carrier of complexes of different stabilities and is an important enzymatic activator (Marschner, 2012).

The sulfur content differed between the genotypes (Table 1). RB011941 was characterized by the highest content of 1.25 $\mathrm{g} \mathrm{dag}^{-1}$, about $20 \%$ higher than the average $\left(1.05 \mathrm{~g} \mathrm{dag}^{-1}\right)$ of the other cultivars. The values obtained were below the 
Table 1. Analysis of variance of macronutrient contents in the +3 leaf of sugarcane.

\begin{tabular}{|c|c|c|c|c|c|c|}
\hline & $\mathrm{N}$ & $\mathrm{P}$ & $\mathrm{K}$ & $\mathrm{Ca}$ & $\mathrm{Mg}$ & $S$ \\
\hline Variety $(\mathrm{A})$ & ns & $*$ & $*$ & ns & $*$ & $*$ \\
\hline Gypsum (B) & ns & ns & ns & ns & ns & ns \\
\hline Interaction $(\mathrm{A} \times \mathrm{B})$ & ns & ns & ns & ns & ns & ns \\
\hline Mean $\left(\mathrm{g} \mathrm{kg}^{-1}\right)$ & 14.61 & 1.35 & 14.03 & 3.23 & 1.48 & 1.11 \\
\hline CV (\%) & 11.33 & 3.7 & 4.05 & 7.04 & 8.71 & 5.17 \\
\hline
\end{tabular}

ns: not significant; ${ }^{*}$ significant at $5 \%$ by the F-test.

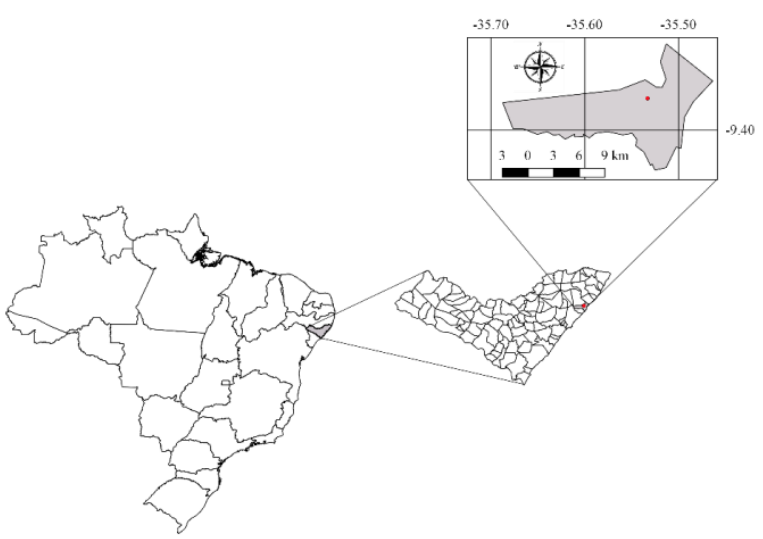

Fig 1. Schematic map of location this study

Table 2. Macronutrient contents in the +3 leaf of three sugarcane varieties.

\begin{tabular}{|c|c|c|c|c|c|c|}
\hline \multirow{2}{*}{ Variety } & $\mathrm{N}$ & $\mathrm{P}$ & $\mathrm{K}$ & $\mathrm{Ca}$ & $\mathrm{Mg}$ & $\mathrm{S}$ \\
\hline & \multicolumn{6}{|c|}{ 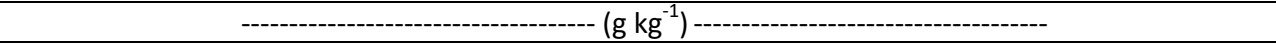 } \\
\hline RB011941 & $14.60 \mathrm{a}$ & $1.15 \mathrm{~b}$ & $14.20 \mathrm{ab}$ & $3.60 \mathrm{a}$ & $1.75 \mathrm{a}$ & $1.25 \mathrm{a}$ \\
\hline RB92579 & $15.65 \mathrm{a}$ & $1.65 \mathrm{a}$ & $14.55 \mathrm{a}$ & $3.10 \mathrm{a}$ & $1.25 \mathrm{~b}$ & $1.05 \mathrm{~b}$ \\
\hline RB991536 & $13.60 \mathrm{a}$ & $1.25 \mathrm{~b}$ & $13.35 \mathrm{~b}$ & $3.00 \mathrm{a}$ & $1.45 \mathrm{ab}$ & $1.05 \mathrm{~b}$ \\
\hline
\end{tabular}

Means followed by different letters in the same column differ at $5 \%$ by the Tukey test.

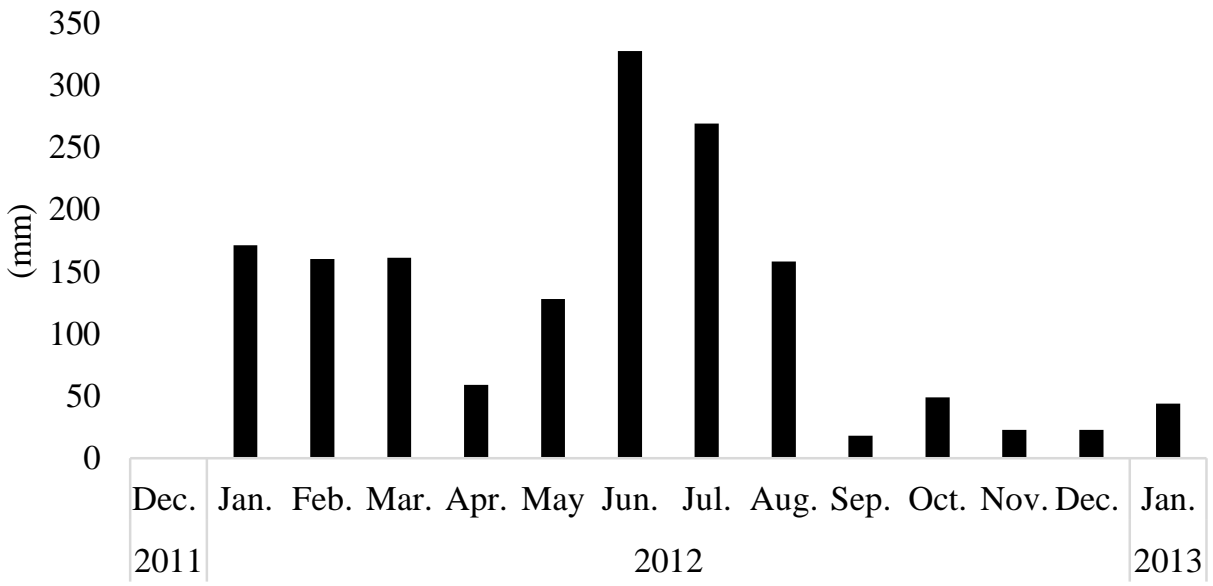

Fig 2. Average monthly rainfall in experimental area during the period of study.

Table 3. Analysis of variance of effeciency of photosynthesis and SPAD index.

\begin{tabular}{|c|c|c|c|c|}
\hline & FV/FM (5h30min) & FV/FM (12h) & YEILD & SPAD \\
\hline Variety (A) & ns & ns & ns & ns \\
\hline Gypsum (B) & ns & ns & ns & ns \\
\hline Interaction $(\mathrm{A} \times \mathrm{B})$ & ns & ns & ns & ns \\
\hline Mean & 0.58 & 0.29 & 0.69 & 21.03 \\
\hline CV (\%) & 17.4 & 8.57 & 11.03 & 17.63 \\
\hline
\end{tabular}


Table 4. Analysis of variance of technological quality of sugarcane.

\begin{tabular}{|c|c|c|c|c|c|}
\hline & Brix & Pol & Purity & Fiber & TRS \\
\hline Variety $(\mathrm{A})$ & * & $*$ & ns & ns & * \\
\hline Gypsum (B) & ns & ns & ns & ns & ns \\
\hline Interaction $(\mathrm{A} \times \mathrm{B})$ & ns & ns & ns & ns & ns \\
\hline Mean & 21.28 & 18.7 & 88.08 & 13.3 & 151.3 \\
\hline CV (\%) & 3.87 & 4.55 & 1.69 & 4.19 & 3.88 \\
\hline
\end{tabular}

ns: not significant; ${ }^{*}$ significant at $5 \%$ by the F-test.

Table 5. Technological quality of three sugarcane varieties

\begin{tabular}{lccccc}
\hline Variety & Brix & Pol & Purity & Fiber & TRS \\
\hline \multicolumn{1}{r}{} & & $-19.75 \mathrm{a}$ & $88.45 \mathrm{a}$ & $13.20 \mathrm{a}$ & $159.75 \mathrm{a}$ \\
RB92579 & $22.35 \mathrm{a}$ & $19.55 \mathrm{~b}$ & $88.35 \mathrm{a}$ & $13.50 \mathrm{a}$ & $150.00 \mathrm{~b}$ \\
RB011941 & $21.20 \mathrm{~b}$ & $17.80 \mathrm{c}$ & $87.45 \mathrm{a}$ & $13.20 \mathrm{a}$ & $144.15 \mathrm{c}$ \\
\hline
\end{tabular}

Means followed by different letters in the same column differ at $5 \%$ by the Tukey test.

Table 6. Soil chemical characteristics.

\begin{tabular}{lccc}
\hline Characteristics & & Depth (cm) & \\
\hline & $0-20$ & $20-40$ & $40-60$ \\
$\mathrm{pH}\left(\mathrm{H}_{2} \mathrm{O} 1: 25\right)$ & 5.8 & 5.1 & 4.8 \\
$\mathrm{Ca}^{+2}\left(\mathrm{cmolc} \mathrm{dm}^{-3}\right)$ & 2.0 & 1.1 & 0.9 \\
$\mathrm{Mg}^{+2}\left(\mathrm{cmolc} \mathrm{dm}^{-3}\right)$ & 1.4 & 0.6 & 0.5 \\
$\mathrm{~K}^{+}\left(\mathrm{cmolc} \mathrm{dm}^{-3}\right)$ & 0.65 & 0.34 & 0.23 \\
$\mathrm{Al}^{+3}\left(\mathrm{cmolc} \mathrm{dm}^{-3}\right)$ & 0 & 0.3 & 0.6 \\
$\mathrm{H}^{+}\left(\mathrm{cmolc} \mathrm{dm}^{-3}\right)$ & 2.0 & 2.4 & 2.6 \\
$\mathrm{H}+\mathrm{Al}\left(\mathrm{cmolc} \mathrm{dm}^{-3}\right)$ & 2.0 & 2.7 & 3.2 \\
$\mathrm{P}\left(\mathrm{mg} \mathrm{dm}^{-3}\right)$ & 46.6 & 38.1 & 14.8 \\
$\mathrm{~S}\left(\mathrm{mg} \mathrm{dm}^{-3}\right)$ & 37 & 37 & 36 \\
$\mathrm{Fe}\left(\mathrm{mg} \mathrm{dm}^{-3}\right)$ & 75.0 & 74.0 & 64.0 \\
$\mathrm{Cu}\left(\mathrm{mg} \mathrm{dm}^{-3}\right)$ & 3.5 & 2.9 & 2.1 \\
$\mathrm{Zn}\left(\mathrm{mg} \mathrm{dm}^{-3}\right)$ & 2.1 & 1.2 & 0.8 \\
$\mathrm{Mn}\left(\mathrm{mg} \mathrm{dm}^{-3}\right)$ & 4.4 & 1.6 & 1 \\
$\mathrm{~B}\left(\mathrm{mg} \mathrm{dm}^{-3}\right)$ & 0.23 & 0.20 & 2.18 \\
$\mathrm{M} . \mathrm{O} .\left(\mathrm{dag} \mathrm{kg}^{-1}\right)$ & 3.1 & 2.4 & 2.1 \\
\hline
\end{tabular}

ranges considered adequate by Orlando Filho (1993), Malavolta et al. (1997), and Raij (2011). The results were similar to those observed by Silva et al. (2017a).

The mean foliar values of the macronutrients of the genotypes RB011941, RB92579 and RB991536 subjected to gypsum doses presented the following concentration order: nitrogen $>$ potassium $>$ calcium $>$ magnesium $>$ phosphorus $>$ sulfur, similar to what was observed by Silva et al. (2017a).

\section{Photochemical efficiency and SPAD}

Application of mineral gypsum and sugarcane genotypes did not influence photochemical efficiency (Table 3). According to Dias and Marenco (2007), Fv/Fm values (measured at dawn) less than 0.7 indicate chronic photo-inhibition. Following this criterion, this type of inhibition was verified only in RB92579. Gonçalves et al. (2010) studied the effect of water deficit on four sugarcane genotypes and observed that genotypes did not differ in Fv/Fm.

In a study conducted by Silva et al. (2007) with drought tolerant sugarcane genotypes in southern Texas, the authors also did not observe a difference between genotypes. Still, according to the authors, plants that present intact photosynthetic apparatus present mean values of the Fv/FM ratio varying from 0.75 to 0.85 . The lower values reflect photo-oxidative damage caused by photo-inhibition at the PSII reaction center. The results of the present study are within the range established by Silva et al. (2007), indicating that the plants did not suffer photo-oxidative damage.

Effective quantum efficiency (YIELD) did not vary between genotypes and mineral gypsum doses. This was due to rainfall being considered adequate for in the region of study. Furthermore, even in the dry season, the plants could explore deeper layers of the soil and extract the stored water without affecting the photochemical efficiency of the cane due to having a well-formed root system (Gonçalves et al., 2010). Wanderley Filho (2011), studied biostimulants and rooting agents in sugarcane under water stress. They recorded YIELD results ranging from 0.29 to 0.55 , values below those found in this study, which presented averages of $0.57,0.56$, and 0.63 in genotypes RB011941, RB92579, and RB991536 (Table 3), respectively. The SPAD index was not altered as a function of the evaluated genotypes. Similar results were observed by Silva et al. (2007) in studies with four water stress tolerant sugarcane genotypes in southern Texas, where no differences were observed between genotypes regarding the SPAD index, evaluated 45 days after the start of irrigation treatments. No significant effect of mineral gypsum was observed on the physiological indices (photochemical efficiency and SPAD index) during the period of evaluation, coinciding with the beginning of leaf senescence and with some plants presenting senescent leaves. 


\section{Technological quality of sugarcane}

The analysis of variance detected no interaction effects between the varieties and gypsum doses on the technological quality of sugarcane (Table 1). Gypsum doses did not affect the technological quality of the plants. The varieties were significantly different in terms of Brix, Pol, and TRS.

The highest Brix percentage was obtained by the variety RB92579 (22.35\%), while the lowest content was observed in RB011941 (20.30\%) (Table 5). Silva et al. (2017b) evaluated the technological quality of four sugarcane varieties (RB92579, RB867515, SP813250, and VAT90212) cultivated in a Yellow Latosol, and obtained values $15 \%$ lower than those observed in the present study. Results similar to the present study were observed by Oliveira et al. (2011b), who obtained an average Brix content of approximately $21 \%$ for 11 cultivars grown on a Yellow Argisol.

Regarding the (Pol), RB92579 presented higher content with an average value $10 \%$ higher than the other two varieties. Evaluation of effect of increasing doses of potassium in the sugarcane crop by Pancelli et al. (2015) found an average apparent sucrose content of $20 \%$, similar to those observed in the present study. Oliveira et al. (2017) found an apparent sucrose content of $18 \%$ in the juice of RB92579. According to Fernandes (2011), Pol represents the apparent percentage of sucrose contained in the sugarcane juice, being determined by saccharimetric methods. It is the main attribute for determining the quality of sugarcane and corresponds to 14 to $24 \%$ of the total sugars of sugarcane.

The varieties had similar juice purity (Table 4), in which an average content of $88 \%$ was found. These results resemble those observed by Albuquerque et al. (2016), who evaluated the technological quality of RB92579 subjected to different sources and forms of application of phosphorus, $89 \%$ of apparent purity on average.

The characteristic of sugarcane juice purity is directly related to the quality of the raw material and is influenced by the mineral and vegetal impurities that are added to the sugarcane at the time of harvest (Oliveira et al., 2015). It is an attribute that represents the amount of sucrose contained in the soluble solids, being an important indicator of the sugarcane maturity, by which the more mature, the greater the accumulation of sucrose and, consequently, the greater the purity (Lavanholi, 2008). According to the rules established by Consecana (2006), mills can only refuse to receive cane with less than $75 \%$ purity. In the state of São Paulo, Oliveira et al. (2012) mentioned the purity of $80 \%$ as a reference at the beginning of the harvest, and $85 \%$ at the end of the harvest for the industrialization of sugarcane. Following this criterion, the three varieties of the present study were mature at harvest.

There was no varietal effect for the fiber content (Table 4), with the varieties averaging $13.3 \%$. The fiber represents an attribute of great importance in the sugar-energy sector. From the agricultural point of view, the varieties richer in fiber content are more resistant to tipping, even when subjected to straw removal by fire, and are generally more resistant to pest penetration on the stem. From the industrial point of view, the fiber content is important for the energy balance of the industry, since the fibers are used for the firing in the boilers, generating steam that will be transformed into electrical energy to supply the plant, as well as for surplus sale (Lavanholi, 2008).

In a study evaluating the technological quality of seven varieties of sugarcane cultivated under semi-arid conditions, Oliveira et al. (2015), reported the average value of $14.83 \%$, which is higher than those obtained in the present study. With the increase in fiber percentage, the resistance to juice extraction increases. Therefore, a value from 10.5 to $12.5 \%$ has been recommended for a good industrial yield (Oliveira et al., 2009). Fernandes (2011), indicated that the average fiber content should be between 10 and $11 \%$. However, in the northeast region, the fiber content is higher due to the higher evapotranspiration at the time of cane harvest (Silva et al., 2017b).

Out of all technological quality variables that analyzed, total recoverable sugar (TRS) is one of the prominent attributes. It is due to the fact that the current sugarcane payment system, adopted by most sugar-energy industries, follows the methodology described by Consecana (2006), which uses the TRS value to determine the price paid to producers. Observing this parameter, it was verified that the variety RB92579 presented better results, being able to reach levels higher than $159 \mathrm{~kg}$ of TRS $\mathrm{t}^{-1}$, about $15 \%$ higher than the average of the other two genotypes (Table 2). Silva et al. (2014) evaluated the technological quality of RB92579 under different fertilization sources and recorded a TRS variation from 139.81 to $149.13 \mathrm{~kg} \mathrm{t}^{-1}$.

The TRS represents all cane sugars in the form of invert sugars, although other reducing substances present in the sugarcane juice may be included. In plants, the conversion of sucrose into glucose and fructose is an inversion reaction, occurring during the metabolism of photosynthesis and respiration of the plant. Therefore, the knowledge on TRS content of plant is important to evaluate the quality of the raw material (Fernandes, 2011).

\section{Materials and methods}

\section{Location and characteristics of the experimental area}

The experiment was conducted in the field, in the municipality of São Luiz do Quitunde (9022' S and 3532' W), in the Zona da Mata of Alagoas, Brazil (Figure 1). The climate was characterized as monsoon tropical with dry summers according to Köppen classification. The mean annual rainfall is $2,220 \mathrm{~mm}$. However, during the test, the accumulated rainfall was 1,681 $\mathrm{mm}$ (Figure 2), and the mean temperature $27.5^{\circ} \mathrm{C}$ (Clemente et al., 2017).

The soil of the experimental area was classified as Fluvic Neosol (Embrapa, 2013). Before the installation of the study, soil sampling was performed in the layers of $0.0-0.2,0.2-0.4$, and 0.4-0.6 $\mathrm{m}$, for chemical characterization (Table 6). The determined attributes were: $\mathrm{pH}\left(\mathrm{H}_{2} \mathrm{O}\right), \mathrm{Ca}^{2+}, \mathrm{Mg}^{2+}, \mathrm{K}^{+}, \mathrm{Al}^{3+}$, $(\mathrm{H}+\mathrm{Al}), \mathrm{P}, \mathrm{S}, \mathrm{Fe}^{2+}, \mathrm{Cu}^{2+}, \mathrm{Mn}^{2+}, \mathrm{Zn}^{2+}, \mathrm{B}, \mathrm{Ca}^{2+}$, and TOC (total organic carbon). $\mathrm{Ca}^{2+}, \mathrm{Mg}^{2+}$, and $\mathrm{Al}^{3+}$ were extracted with 1.0 $\mathrm{mol} \mathrm{L}^{-1} \mathrm{KCl}$ and determined by titration. $\mathrm{Fe}^{2+}, \mathrm{Cu}^{2+}, \mathrm{Mn}^{2+}$, $\mathrm{Zn}^{2+}$, and $\mathrm{K}$ were extracted using Mehlich-1. The $\mathrm{P}$ was determined by colorimetry; $\mathrm{K}^{+}$and $\mathrm{Na}^{+}$by flame photometry, $\mathrm{Fe}^{2+}, \mathrm{Cu}^{2+}, \mathrm{Mn}^{2+}$ and $\mathrm{Zn}^{2+}$ by atomic absorption spectrophotometry. The $(\mathrm{H}+\mathrm{Al})$ was extracted using $0.5 \mathrm{~mol}$ $\mathrm{L}^{-1}$ calcium acetate and determined by titration. All analyses were performed according to the methodologies described by Embrapa (2009). 


\section{Experimental design and applied treatments}

The experimental design was a randomized block design with four replications, in a $3 \times 5$ factorial scheme, consisting of three sugarcane varieties (RB011941, RB92579, and RB991536) and five doses of mineral gypsum (0 Mg ha ${ }^{-1}, 2.5$ $\mathrm{Mg} \mathrm{ha}^{-1}, 5.0 \mathrm{Mg} \mathrm{ha}^{-1}, 10.0 \mathrm{Mg} \mathrm{ha}^{-1}$, and $\left.20.0 \mathrm{Mg} \mathrm{ha}^{-1}\right)$. The plots were constituted by five 10-m-long furrows, spaced $1.10 \mathrm{~m}$, with the useful area being represented by the three central furrows with $8 \mathrm{~m}$ length $(1 \mathrm{~m}$ of each end was discarded), totaling $33 \mathrm{~m}^{2}$ (Clemente et al., 2017).

The varieties were chosen because of the high adaptability, yield, and representativeness that they have in Brazil (Silveira et al., 2015; Silva et al., 2017a). The criteria for the choice of mineral gypsum doses were described in a study by Clemente et al. (2017). The gypsum used in the experiment originated from gypsum mineral deposits $\left(\mathrm{CaSO}_{4} \cdot 2 \mathrm{H}_{2} \mathrm{O}\right)$, from Araripe, Pernambuco. The gypsum used contained $45.86 \% \mathrm{CaO}, 20.30 \% \mathrm{~S}$, and $19.18 \%$ moisture (Clemente et al., 2017).

\section{Soil tillage and sugarcane planting}

Having the results of the soil analysis (Table 6), acidity was corrected using dolomitic limestone at the dose calculated by the method that aims to raise base saturation to $60 \%$, according to Oliveira et al. (2007).

The soil was prepared using a heavy harrow to destroy crop residues, followed by leveling and opening of the furrows. Gypsum doses were uniformly applied at the bottom of the furrow to a depth of approximately $20 \mathrm{~cm}$ over a length of $10 \mathrm{~m}$. Subsequently, stems of the varieties RB011941, RB92579, and RB991536 were distributed in the furrows, using a planting density of 15 cuttings $\mathrm{m}^{-1}$. All plots received $700 \mathrm{~kg} \mathrm{ha}^{-1}$ of the formula 14-00-18 (ammonium sulfate $20 \% \mathrm{~N}$ and potassium chloride $-58 \% \mathrm{~K}_{2} \mathrm{O}$ ). Manual weed control was performed only up to 30 days after bud emergence. Irrigation $(30 \mathrm{~mm})$ was performed at 2 and 20 days after the start of the experiment (Clemente et al., 2017).

\section{Analyzed variables}

In order to understand the effects of the association of gypsum doses on the different sugarcane varieties, nutritional, physiological, and technological quality aspects of the three genotypes were evaluated in the cane plant cycle.

\section{Assessment of the nutritional status of plants}

The nutritional status was assessed at the maximum growth stage of the plants, eight months after sugarcane planting, by quantifying the macronutrient foliar contents. For the assessment, twenty +3 leaves (Dewlap) were randomly collected in the useful area of each plot. After collection of the leaves, the elimination of the central vein and separation of $20 \mathrm{~cm}$ from the median region were preceded. After washing, they were subjected to drying in an oven with forced-air circulation for 72 hours at $65{ }^{\circ} \mathrm{C}$. The samples were then ground in a Willey mill, and macronutrients ( $\mathrm{g} \mathrm{kg}$ $\left.{ }^{1}\right)$ were determined according to the method described by Malavolta et al. (1997). The $\mathrm{N}$ was extracted by sulfuric digestion and determined by the Kjeldahl method. The other nutrients were extracted by nitro-perchloric digestion. P was determined colorimetrically by the blue color development, through the reduction of the phosphomolybdic complex. The $\mathrm{K}$ was determined by flame photometry, $\mathrm{Ca}$ and $\mathrm{Mg}$ by the method of atomic absorption spectrophotometry, and $\mathrm{S}$ by barium sulphate turbidimetry.

\section{Physiological analyses}

To perform the physiological analyses, the plants were selected and identified, using one plant from the central row of each plot to analyze SPAD index and photochemical efficiency at 367 DAP. The evaluations were carried out in this period to coincide with the drought and possible stress in the plants.

The SPAD index was used as an indirect measure of chlorophyll (SPAD index), through non-destructive method, using the chlorophyll meter SPAD-502 (Minolta Corporation, Ramsey, Japan). Means were obtained from ten readings per plot, using the middle third of the leaf $(+1)$ of each plant.

Photochemical efficiency was evaluated using the limb of the central part of the leaf $(+1)$ of one plant per each plot. Maximum quantum efficiency ( $\mathrm{Fv} / \mathrm{Fm}$ ) was measured at two times: (1) at 5:30 a.m., before dawn (chronic photoinhibition measure); and (2) at noon (dynamic photoinhibition measure). The measurements were quantified in vivo with a portable fluorometer (WALZ-PAM-2500), which measured light by pulse-amplitude-modulation (PAM) to promote the closure of the PSII reaction centers, according to the method described by Maxwell and Johnson (2000), with the Fv/Fm being measured after dark conditioning, with metal tweezers for 20 minutes. The effective quantum efficiency of PSII (DPSII) was measured between 8:00 a.m. and 10:00 a.m. in the same leaves, according to Schreiber et al. (1995).

\section{Technological quality of sugarcane}

At 402 days after planting, the shoots of 8 plants were randomly sampled in the useful area of each plot. The canes were tipped and the straw was removed. Subsequently, the canes were sent to the Agroindustrial Laboratory of the Santo Antônio Plant in São Luis do Quitunde/AL. The samples were passed through a forage chopper and then subsamples were collected to determine the technological attributes of sugarcane, according to the methodology of Fernandes (2011). The subsamples were subjected to an automatic hydraulic press under pressure of $250 \mathrm{~kg} \mathrm{~cm}^{-2}$ for $1 \mathrm{~min}$ and then the juice was collected. In the juice, total soluble solids (oBrix) were quantified with a digital refractometer. The percentage of apparent sucrose in the juice (Pol) was obtained by means of a saccharimeter. The fiber percentage and theoretical recoverable sugar (TRS) were determined according to the equations described in Fernandes (2011).

\section{Statistical analysis}

The results were submitted to analysis of variance at $5 \%$ probability by the $\mathrm{F}$ test, and the means compared by the Tukey test for qualitative data. Regression analysis was performed for quantitative data (Ferreira, 2011). 


\section{Conclusion}

Mineral gypsum did not influence the physiological, nutritional, and technological quality aspects of sugarcane genotypes. The varieties presented differences in leaf contents, but none of which presented a higher content for all the macronutrients. The RB92579 variety presented the best industrial quality.

\section{Acknowledgements}

We would like to thank Usina Santo Antonio for the logistical support in conducting the study and to the CAPES Coordination for the Improvement of Higher Education Personnel (Coordenação de Aperfeiçoamento de Pessoal de Nível Superior), by financial support and scholarships.

\section{References}

Abreu MLD, Silva MDA, Teodoro I, Holanda LAD, Sampaio Neto GD (2013). Growth and productivity of sugarcane varieties as affected by water availability in the Coastal Tablelands of the Alagoas State, Brazil. Bragantia. 72(3): 262-270.

Albuquerque AW, Sá LA, Rodrigues WA, Moura AB, Oliveira Filho MDS (2016) Growth and yield of sugarcane as a function of phosphorus doses and forms of application. $R$ Bras Eng Agríc Ambient 20(1), 29-35.

Bloom AJ The increasing importance of distinguishing among plant nitrogen sources (2015) Curr Opin Plant Biol. 25, 1016.

Calheiros AS, Oliveira MW, Ferreira VM, Barbosa GVS, Santiago AD, Aristides EVS (2012) Production of biomass, from sugar and protein in function of sugarcane varieties and phosphorous fertilization. Semina Ciênc Agrár. 33(2), 809-818.

Canfield DE, Glazer AN, Falkowski PG (2010) The evolution and future of Earth's nitrogen cycle. Science 330, 192-196.

Chalita (1991) Calibração da adubação potássica através da análise química do solo para cultura da cana-de-açúcar. Dissertation, Universidade de São Paulo, Piracicaba. p 75.

Clemente PR, Bezerra BKL, Silva VSG, Santos JCM, Endres L (2017) Root growth and yield of sugarcane as a function of increasing gypsum doses. Pesqui Agropecu Trop 47(1), 110-117.

Consecana - Conselho dos Produtores de Cana-de-Açúcar, Açúcar e Álcool do Estado de São Paulo (2006) Manual de Instruções. 5o ed. Piracicaba, Consecana. P 112.

Dias DP, Marenco RA (2007) Photosynthesis and photoinhibition in mahogany and acariquara as a function of irradiance and leaf temperature. Pesq Agropec Bras. 22 (19): 305-311.

Embrapa - Empresa Brasileira de Pesquisa Agropecuária (2009) Manual de análise química de solo, planta e fertilizantes. Embrapa, Brasília. p 627.

Embrapa - Empresa Brasileira de Pesquisa Agropecuária (2013) Sistema brasileiro de classificação de solos. Embrapa, Brasília. p 353.

Fernandes AC (2011) Cálculos na agroindústria da cana-deaçúcar. Stab, Piracicaba. p 416.

Ferreira DF (2011) Sisvar: a computer statistical analysis system. Ciênc Agrotec. 35 (6): 1039-1042.
Flores RA, Prado RM, Politi LS, Almeida TBF (2012) Potássio no desenvolvimento inicial da soqueira de cana crua. Pesq Agropec Trop. 42(1):106-111.

Gonçalves ER, Ferreira VM, Silva JV, Endres L, Barbosa TP, Duarte WG (2010) Trocas gasosas e fluorescência da clorofila a em variedades de cana-de-açúcar submetidas à deficiência hídrica. R Bras Eng Agríc. Ambiental. 14 (4), 378-386.

Lavanholi MGDP (2008) Qualidade da cana-de-açúcar como matéria prima para a produção de açúcar e álcool. In: Dinardo -Miranda LL, MGA (Org.) Cana-de-acucar. 1: 697722.

Losordo Z, Mcbride J, Rooyen JV, Wenger K, Willies D, Froehlich A, Lynd L (2016) Cost competitive secondgeneration ethanol production from hemicellulose in a Brazilian sugarcane biorefinery. Biofuels Bioprod Biorefin. 10 (5), 589-602, 2016.

Malavolta E, Vitti GC, Oliveira AS (1997) Avaliação do estado nutricional das plantas - princípio e aplicações. ABPPF, Piracicaba. p 319.

Marschner P (2012) Mineral Nutrition of higher plants. 3rd edn. Elsevier, San Diego. 651 p.

Maxwell K, Johnson GN Chlorophyll fluorescence: a pratical guide. J Exp Bot. 51 (345): 659-68.

Morelli JL, Dalben AE, Almeida JOC, Demattê JLI (1992) Calcário e gesso na produtividade da cana-de-açúcar e nas características químicas de um latossolo de textura média álico. Rev Bras Cienc Solo. 16(2), 187-194.

Moura Filho G, Albuquerque AW, Moura AB, Santos, ACl, Filho MSO, Silva LC (2014) Nutritional diagnosis and yield of sugarcane varieties in Urtisols. $R$ Bras Eng Agríc Ambiental. 18(11):1102-1109.

Oliveira AR, Braga MB, Walker AM (2015) Behavior vegetative and technological characteristics sugarcane cultivars under water stress in semi-arid conditions of Brazil. Rev Bras Geo Fis. 8:525-541.

Oliveira DC, Oliveira MW, Pereira MG, Gomes TCA, Silva VSG, Oliveira TBA (2017) Stalk productivity and quality of three sugarcane varieties at the beginning, in the middle, and at the end of the harvest. Afr J Agric Res. 12(4), 260-269.

Oliveira ECA, Freire FJ, Oliveira AC, Simões Neto DE, Rocha AT, Carvalho LA (2011a) Productivity, water use efficiency, and technological quality of sugarcane subjected to differents water regimes. Pesq Agropec Bras 46(6): 617625

Oliveira ECA, Freire FJ, Oliveira RI, Freire MBGS, Simões Neto DE, Silva SAMD (2010) Extração e exportação de nutrientes por variedades de cana-de-açúcar cultivadas sob irrigação plena. Rev Bras Ciên Solo, 34(4): 1343-1352.

Oliveira ECA, Freire FJ, Oliveira RI, Oliveira AC, Freire MBGS (2011b) Accumulation and allocation of nutrients in sugar cane. Rev Cienc Agron. 42(3), 579-588.

Oliveira EL, Andrade LAB, Faria MA, Evangelista AWP, Morais $A R$ (2009) Use of pot still vinasse and nitrogen in irrigated and unirrigated sugar cane. Pesq Agropec Bras. 44(11):1398-1403.

Oliveira FM, Aspiazú I, Kondo MK, Borges ID, Pegoraro RF, Vianna EJ (2012) Avaliação tecnológica de variedades de cana-de-açúcar influenciadas por diferentes adubações e supressões de irrigação. Ceres. 59(6): 832-840.

Oliveira MW, Freire FM, Macêdo GAR, Ferreira JJ (2007) Nutrição mineral e adubação da cana-de-açúcar. Inf Agropec, 28 (1), 30-43. 
Orlando Filho J (1993) Calagem e adubação da cana-deaçúcar. In: Câmara GMS, Oliveira EAM (ed) Produção de cana-de-açúcar. FEALQ/USP, Piracicaba. 133-146.

Pancelli MA, Prado RM, Flores RA, Almeida HJ, Moda LR, Souza Junior JP (2015). Growth, yield and nutrition of sugarcane ratoon as affected by potassium in a mechanized harvesting system. Aust J Crop Sci. 9(10), 915924.

Pereira LF, Ferreira VM, Oliveira NG, Sarmento PL, Endres L, Teodoro I (2017) Sugars levels of four sugarcane genotypes in different stem portions during the maturation phase. An Acad Bras Ciênc. 89(2), 1231-1242.

Raij BV (2011) Fertilidade do solo e manejo de nutrientes. International Plant Nutrition Institute, Piracicaba, 2011. p.420

Rocha AT, Oliveira AC, Rodrigues NA, Andrade Junior ML, Freire FJ (2008) Emprego do gesso do Araripe na melhoria do ambiente radicular da cana-de-açúcar. Rev Bras de Ciênc Agrár. 3(4), 307-312.

Schreiber U, Hormann H, Neubauer C, Klughammer C (1995) Assessment of photosystem II photochemical quantum yield by chlorophyll fluorescence quenching analysis. Funct Plant Biol. 22(2), 209-220.

Silva MA, Jifon JL, Silva JAG, Sharma V (2007) Use of physiological parameters as fast tools to screen for drought tolerance in sugarcane. Braz J Plant Physiol. 19(3):193-201.

Silva VSG, Oliveira MW, Oliveira DC, Oliveira TBA, Pereira MG, Nogueira, CHC (2017a) Nutritional diagnosis of sugarcane varieties in a Yellow Oxisol during three agricultural seasons. Afr J Agric Res, 12(1), 50-57.

Silva VSG, Oliveira MW, Silva $A C$, Silva $A F$, Galvão $E R$, Santana MB (2017b) Agro-industrial quality in plant, first and second ratoon crops of sugarcane varieties Aust J Crop Sci. 9(10), 915-924.

Silva WP, Almeida CDGC, Silva VGF, Bastos GQ, Marques KPP (2014) produtividade e qualidade tecnológica da cana-deaçúcar sob diferentes fontes de adubação. Rev Bras Agric Irrig. 8(6), 476-487.

Silveira LCl, Brasileiro BP, Kist V, Daros E, Peternelli LA (2015) Genetic diversity and coefficient of kinship among potential genitors for obtaining cultivars of energy cane $^{1}$. Rev Ciênc Agron, 46(2):358-368.
Simões Neto DE, Oliveira ACD, Freire FJ, Freire MBGS, Oliveira ECA, Rocha ATD (2015) Phosphorus fertilization for sugarcane in representative soils for cultivating this species in the Brazilian Northeast. Pesq Agropec Bras. 50(1): 73-81.

Smeets EMW, Bouwmanw LF, Van Vuuren DP, Posthuma A (2009) Contribution of $\mathrm{N}_{2} \mathrm{O}$ to the greenhouse gas balance of first generation biofuels. Glob Change Biol. 15(1), 1-23.

Sousa RTX. Korndörfer GH, Soares, BRA, Fontoura PR (2013) Phosphate fertilizers for sugarcane used at pre-planting (phosphorus fertilizer application). J Plant Nutr. 38(9), 1444-1455.

Souza DMG, Miranda LN, Oliveira SA (2007) Acidez do solo e sua correção. In: Novais RF, Alvarez VH, Barros NF, Fontes RL, Cantarutti RB, Neves JCL Fertilidade do solo. Viçosa: Sociedade Brasileira de Ciência do Solo, 205-274.

Souza JL, Moura Filho, GM, Lyra RFF, Teodoro I, Santos EA, Silva JL, Silva PRT, Cardim AH, Amorim EC (2004) Análise da precipitação pluvial e temperatura do ar na região do tabuleiro costeiro de Maceió, AL, período de 1972-2001. Rev Bras de Agrometeorol. 12 (1), 131-141.

Waclawovsky AJ, Sato PM, Lembke CG, Moore PH, Souza GM (2010) Sugarcane for bioenergy production: an assessment of yield and regulation of sucrose content. Plant Biotechnol J. 8(3): 263-276.

Wanderley Filho HC L (2011) Uso de bioestimulantes e enraizadores no crescimento inicial e tolerância à seca em cana-de-açúcar. Dissertation, Universidade Federal de Alagoas, Rio Largo. 